УДК 811.161.2'37

DOI https://doi.org/10.26661/2414-9594-2021-1-16

\title{
СИМВОЛІЧНО-МЕТАФОРИЧНИЙ ОБРАЗ «ЖИТТЯ» У ПОЕТИЧНОМУ ІДІОСТИЛІ ТОДОСЯ ОСЬМАЧКИ
}

\author{
Лисенко Н. О. \\ кандидат філологічних наук, доцент, \\ дочент кафедри фундаментальної та мовної підготовки \\ Національний фармачевтичний університет \\ вул. Пушкінська, 53, Харків, Україна \\ orcid.org/0000-0001-8607-2213 \\ natalilisenko1977@gmail.com
}

Вялих І. Ю.

старший викладач кафедри документознавства та української мови

Національний аерокосмічний університет імені М. С. Жуковського

«Харківський авіаційний інститут»

вул. Чкалова, 17, Харків, Україна

orcid.org/0000-0002-7761-9253

vialykhinna@gmail.com

\begin{abstract}
Ключові слова: ідіостиль, ідіостилістична домінанта, символіко-метафоричний образ «життя», образна паралель, семно-компонентний аналіз.
\end{abstract}

У статті досліджено особливості реалізації символічно-метафоричного образу «життя» у поетичній мові Тодося Осьмачки. Уперше детально описано образні паралелі «життя - дорога», «життя - книга», «життя театр (чорна драма)», традиційні для поетики українських символістів, що дозволяє розглядати творчу спадщину митця крізь призму символістської поетичної традиції.

Для аналізу семантичних перетворень застосовано порівняльний метод та семно-компонентний аналіз, що дозволяє проаналізувати структуру метафоричного / символічного значення, установити співвідношення компонентів-сем, вивчити семантичні процеси під час метафоризації слова. Тодось Осьмачка є автором особливої трисферної поетичної моделі світу, яка зумовлює розподіл уживаних образів на такі, що відповідають «астральній» моделі світу, «земній» моделі світу та сфері почуттів. Установлено, що в багатьох випадках образна парадигма життя взаємодіє 3 комплексами «тваринний світ» та «сфера почуттів», зокрема із традиційними орнітологічними символами «сокіл» і «орел», а також із типовими для української поетичної моделі світу образами «душа» і «серце».

Для дослідження свідомо обрано твори різних періодів творчості поета, оскільки це дає можливість простежити розвиток метафоричних парадигм. Попри те, що символічно-метафоричний образ «життя» не належить до ідіостилістичних домінант у ранньому періоді (збірки «Круча» (1922 р.), «Скитські вогні» (1925 р.), «Клекіт» (1929 р.), доведено необхідність дослідження і тих образів, що перебувають на периферії. Ідіостилістичні домінанти не $є$ константами, із плином часу частотність i символічне наповнення можуть змінюватись. Доведено, що більшість метафор із компонентом «життя» реалізовані у збірці «Китиці часу» (19431948 роки), що дає змогу вважати їх новоствореною домінантою ідіостилю. Для встановлення первинного значення традиційних образів-символів використано роботи Миколи Костомарова «Слов’янська міфологія», Джека Тресиддера «Словарь символов», семно-компонентний аналіз проведено із застосуванням одинадцятитомного «Словника української мови». 


\title{
SYMBOLIC AND METAPHORICAL WAY OF "LIFE" IN THE POETIC IDIODYSTLE OF TODOS OSMACHKA
}

\author{
Lysenko N. O. \\ Candidate of Philological Sciences, Associate Professor, \\ Associate Professor at the Department of Fundamental and Language Training \\ National University of Pharmacy \\ Pushkinska str., 53, Kharkiv, Ukraine \\ orcid.org/0000-0001-8607-2213 \\ natalilisenko1977@gmail.com \\ Vialykh I. Yu. \\ Senior Lecturer at the Department of Documentation and Ukrainian Language \\ National Aerospace University "Kharkiv Aviation Institute" \\ Chkalova str., 17, Kharkiv, Ukraine \\ orcid.org/0000-0002-7761-9253 \\ vialykhinna@gmail.com
}

Key words: idiostyle, idiostylistic dominant, symbolic-metaphorical way of "life", figurative parallel, semantic component analysis.
The article investigates the peculiarities of the symbolic and metaphorical way of "life" realization in Todos Osmachka's poetic language. For the first time, the figurative parallels "life - road", "life - book", "life - theater (black drama)", traditional for the poetics of Ukrainian symbolists, have been described in detail, which allows considering the poet's creative heritage through the prism of symbolist poetic tradition.

To analyze the semantic transformations there have been applied the comparative method and semantic component analysis, which allows analyzing the structure of metaphorical (symbolic) meaning, establishing the ratio of semantic components, studying the semantic processes in metaphorization of a word.

Todos Osmachka is the author of a special three-sphere poetic model of the world, which determines the division of the images used into those corresponding the "astral" model of the world, the "earthly" model of the world, and the domain of the feelings. It has been found out that in many cases the lifestyles interact with the complexes "animal world" and "domain of feelings", in particular with traditional ornithological images-symbols "falcon" and "eagle", as well as with the images "soul" and "heart" typical for the Ukrainian poetic model of the world.

The poet's creative works of different periods have been deliberately chosen for the study, as this makes it possible to trace the development of figurative paradigms. Despite the fact that the symbolic and metaphorical way of life does not belong to the idiostylistic dominants in the early period (miscellanea "Bluff" (1922), "Scythian Lights" (1925), "Squawk" (1929)), the necessity of research of those images on the periphery has also been proven. Idiostylistic dominants are not constants, the frequency and symbolic content of the image may change over the time. It has been proven that most of the metaphors with the component of life were realized in the miscellanea "Tassels of Time" (1943-1948), which allows our considering those a newly created dominant of idiostyle.

To establish the primary meaning of traditional images-symbols, the works of Mykola Kostomarov "Slavic Mythology", Jack Tresidder "Dictionary of Symbols" were used, the semantic component analysis has been performed using an eleven-volume "Dictionary of the Ukrainian language". 
Постановка проблеми. Художні твори відбивають процеси, характерні для певного етапу розвитку літературної мови. Саме тому всебічне вивчення авторських ідіостилів (опис трансформацій традиційних образів-символів, архетипових та індивідуальних авторських образів) - передумова якісного дослідження історії національної художньої мови.

Детермінованість творчості митців слова традиціями та поетичною мовою відповідного періоду не викликає сумніву в багатьох українських дослідників. Ми завжди дотримувалися цього твердження в наших попередніх розвідках [9].

Поетичній мові, специфіці метафор і символів у представників символістської течії приділили увагу у своїх роботах Л. Ставицька [12], Ю. Юсип-Якимович [16], І. Цуркан [15], С. Белевцова [1].

Специфіку метафоричного образу життя вивчають У. Галів [3], О. Дунаєвська і Т. Чаюк [5], Л. Грижак і М. Маковійчук [4], Л. Кравець [8] та інші. «Життя» як концепт досліджують М. Бобро [2] та Л. Мініч [10].

У вагомих працях таких вітчизняних дослідників, як М. Слабошпицький, Н. Зборовська, О. Лапко, С. Маринкевич, В. Пахаренко, В. Барча, образна система творів Т. Осьмачки розглядається суто в літературознавчому плані. Отже, натепер лінгвістичний аспект трансформації традиційних образів-символів у поетичному ідіостилі Т. Осьмачки залишаються поза увагою дослідників, що й доводить актуальність нашої роботи. У своїх попередніх розвідках ми детально описали семантичні процеси та механізм утворення символічних паралелей для ідіостилістичних домінант, проте специфіка метафоричного образу життя як маркера належності до символістської літературної течії також потребує окремого дослідження.

Мета статті. Метою нашої розвідки є дослідження трансформацій образу «життя» у складі метафор у поетичній мові Тодося Осьмачки із застосуванням семно-компонентного аналізу.

Виклад основного матеріалу дослідження. Для створення образу «життя» Тодось Осьмачка користується традиційними для символістів паралелями - «буття - дорога» (варіант - «життя дорога») [12, с. 68]. Також його метафори перегукуються 3 народнопоетичною образністю: «Йому вже одкурило тридцять років на битому життєвому илляху» [13, с. 59]. Образ побудовано 3 використанням зорових асоціацій: курява, що залишилася на дорозі, співвідноситься із життевим шляхом людини.

У контексті «I не найти мені уже ніколи в долині рідній сокола прудкого, ані на горах сніжсаних орла - догнати в світі молоді літа та їх колеса повернуть ізнов на ті иляхи, що вже давно у темну землю завалились глухо, немов пі⿱ лід мандрівник в завірюху» [13, с. 115] автор користується тією ж образною паралеллю «життя дорога», що відбита, наприклад, у таких рядках народної пісні: «Як запряжу сірі воли, коні воронії, та поїдьмо доженемо літа молодії» [6, с. 116]. За аналогією до згаданої образної паралелі Т. Осьмачка здійснює перенесення «молоді літа - віз» (або інший засіб пересування). Традиційні народнопоетичні символи орел, сокіл зберігають своє значення, але також починають асоціюватися 3 «молодими літами», молодістю. У рядках «I $\boldsymbol{я}$ похилився <...> простіший за стежку недавню, самітню, і шляхом, похожим на жовтий язик, із глибу пустелі, з безмежної плями <..> народи бігом простували до ями» [13, с. 203] поет знову використовує образну паралель «життя - дорога», деталізує ії: «життя окремої людини - стежина», «життя людства - шлях». Авторський полісемічний символ «яма», близький до образів «безодні», можна тлумачити як аналог «вічності», проте із цією лексемою пов'язані негативні асоціації:

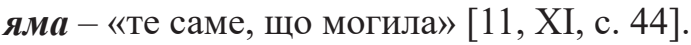

Отже, автор, можливо, вимальовує апокаліптичну картину. Якщо припустити актуалізацію в лексемі переносного значення «те, що характеризується брудом, застоєм, зосередженням низьких інтересів, інтриг, пороків тощо» [11, XI, с. 645], то яма-провалля стає символом загальної деструкції морально-духовних орієнтирів у всієї людської спільноти.

У поетичних рядках «I я між небом зоряним, одягнений в кожух, $і$ між землею сам на дворі, мов здавлений, у палітурках двох книжск ніде не читаних історій. <..> взяла мене поцілувала й потім знов поклала тихо в палітурки. І я аби від поцілунку тихо став в порожній книзі невмирущим і шепотів про серче чуле та вуста всім читачам своїм грядущим» [13, с. 177] поет користується типовою для символістів образною паралеллю «буття - книга», деталізує ії до формули «життя - книга». Окрім того, символ «книги» (не має матеріального вираження) отримує індивідуальні авторські конотації, а саме: стає символом творчої спадщини, що залишає по собі митець прийдешнім поколінням.

У контексті «Сило Божа $<$... кожна летюча люоська куля - лише реп'ях в твоїм плащуі» $[13$, с. 168$]$ залежно від того, яка із семем актуалізується в лексемі «куля», можна говорити про створення двох різних образів. 3 актуалізацією семеми «предмет, що має таку форму» (кулі), а саме: земна куля - планета Земля [11, IV, с. 392], автор змальовує образ Землі - однієї з багатьох планет. Варто зауважити, що образ Бога - творця Землі та земного буття -належить до часто інтерпретованих і популярних у Т. Осьмачки. Якщо 
припустити актуалізацію семеми «маленький свинцевий або сталевий снаряд для стрільби із ручної вогнепальної зброї < .. >» [11, IV, с. 392], то можна говорити, що бінарма людська куля, очевидно, має асоціюватися із життям окремого індивіда. Підставою для виникнення асоціацій стає розмір кулі. Куля символізує незначущість окремого життя для масштабів всесвіту. Створений образ («летюча куля») є динамічним. У другому запропонованому варіанті автор користується індивідуальною образною паралеллю «життя куля». Очевидно, має місце такий перебіг асоціацій: народження - постріл, життя - рух, смерть влучення в мішень.

Верх (небо) співвідноситься 3 вірою, Богом, душами праведників. Зірки можуть уявлятися Т. Осьмачці подібними до Божих слідів або п'ят голодних і босих співвітчизників-страдників, що «пішли на небо» під час лихоліття: «I батько просить «як-небудь на пудів два <..>». Я ж тільки можу, щзо від мук тут закричать! < .. > П'ятою з Паньківки сліди я позначив. Чиїми ж п'ятами вгорі на небесах мені так світять вечори, як я в сльозах? <..> A ті ж крихти, в ночах жниі, $з$ стола небес хай рідний вітер на папір мені зідме!» $[13$, с. 43]. Образ стає символом завдяки глобальності, значущості зображуваного. На нашу думку, жсиві крихти - більше, ніж пейзажна метафора. Виникнення цього символу - відповідь поета на жахливі умови життя: родина поета голодує, хліб у такій ситуації - найцінніше, він є життям. Архетипний образ верx асоціюється 3 добром, вірою, світлом. Живі крихти, що є нічними світилами, отримують асоціації, пов'язані з верхом.

Сема «життя» спочатку додається до лексеми «хліб», далі - до зірок-крихт. I хоч ми не знаходимо наочної реалізації образу Христа, здається, що автор апелює до символічного духовного причастя (яке, можливо, перегукується 3 образами Таємної (останньої) вечері). Стіл небес і зірки-крихти є символом таїнства причастя в духовно-релігійній площині, але водночас вони є ланцюгом, що пов'язує поета 3 родиною, а отже, стають уособленням малої Батьківщини.

У рядках «мос жсиття ужсе на обрій схилило сонце, як на серп» [13, с. 121] маємо актуалізацію семеми «життєдайна, животворча енергія цього світила», яка зумовлює метафоричне перенесення сонце - життева енергія. Водночас спостерігається взаємодія астроніма 3 рослинною парадигмою. Порівняння обрію й серпа стає можливим через образне розуміння їхньої функціональної тотожності: сонце сідає - обрій «ріже» його навпіл так само, як серп зрізає колосся. Автор користується традиційними конотаціями: захід сонця - кінець дня - кінець життя. Серп асоціативно пов'язаний із кінцем літа - осінню (час смерті рослин), а також сам стинає колосся (отже, убиває).

Знаходимо в Т. Осьмачки варіант загальновідомої символічної паралелі «життя - вогонь, жити горіти»: "Дивися, мій сину, на землю стару. Ото вона сита і чорна, бо сила велика зчорнілих від мук у ній погоріло хліборобських рук, як вугля в вічному горнилі <...> Дивися, мій сину, на землю стару, щзо нами і працею повна <...>» [13, с. 74]. Метафоричний образ «життя-горнила», у якому згорають від важкої праці, на нашу думку, має не тільки негативні конотації. Адже саме важка щоденна праця хлібороба є запорукою фізичного виживання роду. Т. Осьмачка ніколи не зраджує свого коріння, навіть залишивши територію рідної країни, поет ніколи не зрікається народу, з якого походить. Навпаки, психологія селянина-хлібороба, його моральні настанови, природно-наївні, чисті, визначають сутність поета протягом усього життя.

Поет вдається також до використання популярної в символістів образної паралелі «життя театр» у модифікованому вигляді «життя - чорна драма»: «Свята уяво, <..> $з$ твого гнізда мистецтво в шкаралущах щзодня летить в найближчий храм. Але воно чорну драму справляє людині в блисках дум та мрій, коли ніколи вже не знайде храму й назад прилине в серце їй» [13, с. 168-169]; «Може, співи досвітніх півнів у диму розженуть чорні зариси драми» [13, с. 191]. Образна паралель «життя - театр» зазнає в поетичних рядках подальшого розгортання, де, відповідно, «мистецтво - душа людини». Водночас застосовується й перенесення «душа - птах». Основою для створення образу стають давні міфологічні уявлення про душу. На базі паралелі «душа - птах» виникає конструкція «місце, де знаходяться душа й серце, гніздо». Варто зазначити, що в Т. Осьмачки душа рухливий образ, на відміну від серця. Тому душа наділяється здатністю астральних мандрівок.

В обох прикладах використано традиційне символічне значення кольору. У лексемі «драма» актуалізується переносне значення «яка-небудь подія, що приносить горе, страждання i т. ін., в особистому або громадському житті» [11, II, с. 206]. В останньому з наведених прикладів актуальною стає також семема «тяжке душевне переживання» [11, II, с. 406], оскільки йдеться про внутрішній світ конкретного героя, особистості. Характерним є також те, що в обох випадках зв'язок із ядерною семемою не втрачається. Через це образна паралель «життя - театр» є джерелом винятково трагічної образності. Але якщо образи, співвідносні з концептом «людина», здебільшого вирізняються оригінальністю, то метафори життя в Т. Осьмачки конструюються за загальносимволістськими образними паралелями: «життя театр», «життя - шлях». 
Висновки. Під час створення метафор із компонентом «життя», не пов'язаних із лексично-семантичною групою «пори року», автор часто користується загальновідомими символістськими паралелями або їх варіантами: «життя - дорога», «життя - книга» (деталізований варіант моделі «буття - книга»), «життя - чорна драма» (деталізація «життя - театр»). Образ «життя» взаємодіє 3 комплексами «тваринний світ» та «сфера почуттів», зокрема із традиційними орнітологічними образами-символами «сокіл» і «орел», а також із типовими для української поетичної моделі світу образами «душа» $\mathrm{i}$ «серце».

Більшість метафор життя реалізовані у збірці «Китиці часу» (поезії 1943-1948рр.). Очевидно, це пов'язано з тим, що поет як зріла особистість починає більш активно цікавитися проблемами світобудови і світопризначення. Отже, метафори життя можна вважати новоствореною домінантою ідіостилю.

\section{ЛIТЕРАТУРА}

1. Белевцова С. Особливості реалізації міфологем у межах естетики символізму й неокласицизму (на матеріалі творчості В. Свідзінського та М. Драй-Хмари). Лінгвістичні дослідження : збірник наукових праць Харківського національного педагогічного університету імені Г.С. Сковороди. Харків : Вид-во ХДПУ, 2014. Вип. 37. С. 111-116.

2. Бобро М. Аксіологічні та лінгвокультурні параметри концепту «життя» як складника української концептосфери : автореф. дис. ... канд. філол. наук: 10.02.01. Харків, 2018. 20 с.

3. Галів У. Етноцентричне наповнення образу «життя» у поезії Василя Стуса. Актуальні питання гуманітарних наук. 2013. Вип. 7. С. 167-171.

4. Грижак Л. Концептуальні метафори сучасного англомовного пісенного дискурсу. Актуальні питання гуманітарних наук. 2020. Вип 32. С. 99-104.

5. Дунаєвська О., Чаюк T. Метафоризація концепту LIFE / ЖИТTЯ в англомовному поетичному рок-дискурсі (на матеріалі інді-рок-гурту “Imagine dragons"). Science and Education a New Dimension. Humanities and Social Sciences. 2019. Vol. VII (33). P. 31-34.

6. Срмоленко С. Фольклор і літературна мова. Київ : Наукова думка, 1987. 245 с.

7. Костомаров М. Слов’янська міфологія. Київ : Либідь, 1994. 384 с.

8. Кравець Л. Концептуальна метафора в мові української поезії ХX ст. Слов'янські мови : збірник наукових праць. Київ : Вид-во НПУ ім. М.П. Драгоманова, 2018. Вип. 1 (13). С. 136-147.

9. Лисенко Н. Архетипні символи як детермінанти поетичної моделі світу. Вісник Харківського національного університету імені В.Н. Каразіна. Серія «Філологія». 2015. Вип. 73. С. 129-131.

10. Мініч Л. Загальнонаціональні концепти «душа», «життя», «любов», «вода», «земля» у поезії М. Вінграновського. Рідний край. 2010. Вип. 1. С. 101-105.

11. Словник української мови : в 11-ти т. Київ : Наукова думка, 1970-1980.

12. Ставицька Л. Естетика слова в українській поезії 20-30-х рр. XX ст. Київ : Правда Ярославичів, 2000. $154 \mathrm{c}$.

13. Осьмачка Тодось. Поезії. Київ : Рад. письменник, 1991. 252 с.

14. Тресиддер Дж. Словарь символов. Пер. с англ. Москва: Фаир-Пресс, 1999. 448 с.

15. Цуркан І. Олександр Олесь як медіум між європейським та українським символізмом. Літературний процес: методологія, імена, тендениії : збірник наукових статей. Київ : Вид-во Київського університету імені Бориса Грінченка, 2016. С. 107-113.

16. Юсип-Якимович Ю. Поетична фонетика в дзеркалі семантики: акустичний (слуховий) світ слов'янського символізму. Украӥнське мовознавство. 2017. Вип. 47/2. С. 101-106.

\section{REFERENCES}

1. Belevtsova S. (2014). Osoblyvosti realizatsii mifolohem u mezhakh estetyky symvolizmu y neoklasytsyzmu (na materiali tvorchosti V. Svidzinskoho ta M. Drai-Khmary). [Peculiarities of realization by mythologists within the aesthetics of symbolism and neoclassicism (based on the works of V. Svidzinsky and M. Dry-Khmara)]. Linhvistychni doslidzhennia: zb. nauk. prats KhNPU im. H.S. Skovorody. Kharkiv: Vyd-vo KhDPU. Vol. 37. P. 111-116 [in Ukrainian].

2. Bobro M. (2018). Aksiolohichni ta linhvokulturni parametry kontseptu "zhyttia" yak skladnyka ukrainskoi kontseptosfery [Axiological and linguistic and cultural parameters of the concept of life as a component of the Ukrainian conceptosphere]: avtoref. dys. na zdobuttia nauk. stupenia kand. filol. nauk : 10.02.01. Kharkiv. 20 p. [in Ukrainian].

3. Haliv U. (2013) Etnotsentrychne napovnennia obrazu "zhyttia" v poezii Vasylia Stusa. [Ethnocentric content of the image of "life" in the poetry of Vasyl Stus]. Aktualni pytannia humanitarnykh nauk. Vol. 7. P. 167-171. [in Ukrainian]. 
4. Hryzhak L. (2020) Kontseptualni metafory suchasnoho anhlomovnoho pisennnoho dyskursu. [Conceptual metaphors of modern English song discourse]. Aktualni pytannia humanitarnykh nauk. Vol. 32. P. 99-104. [in Ukrainian].

5. Dunaievska O., Chaiuk T. (2019) Metaforyzatsiia kontseptu LIFE / ZHYTTIA v anhlomovnomu poetychnomu rok-dyskursi (na materiali indi-rok-hurtu "Imagine dragons"). [Metaphorization of the concept of LIFE / LIFE in English poetic rock discourse (based on the material of the indie rock band "Imagine dragons")]. Science and Education a New Dimension. Humanities and Social Sciences. Vol. VII (33). Pp. 31-34. [in Hungary].

6. Ermolenko S. (1987) Folklor i literaturna mova. [Folklore and literary language]. Kyiv: Naukova dumka. 245 p. [in Ukrainian].

7. Kostomarov M. (1994). Slovianska mifolohiia. [Slavic mythology]. Kyiv: Lybid, 384 p. [in Ukrainian].

8. Kravets L. (2018) Kontseptualna metafora v movi ukrainskoi poezii XX st. [Conceptual metaphor in the language of Ukrainian poetry of the XX'th century.]. Slovianski movy: zb. nauk. prats. Kyiv: Vyd-vo NPU im. M.P. Drahomanova. Vol. 1 (13). P. 136-147. [in Ukrainian].

9. Lysenko N. (2015). Arkhetypni symvoly yak determinant poetychnoi modeli svitu. [Archetypical symbols as the determinants of poetic model of the world]. Visnyk Kharkivskoho natsionalnoho universytetu imeni V.N. Karazina. Seriia "Filolohiia”, Vol. 73. P. 129-131 [in Ukrainian].

10. Minich L. (2010) Zahalnonatsionalni kontsepty dusha, zhyttia, liubov, voda, zemlia v poezii M. Vinhranovskoho. [National concepts of soul, life, love, water, earth in the poetry of M. Vingranovsky]. Ridnyi krai. Vol. 1. P. 101-105. [in Ukrainian].

11. Slovnyk ukrainskoi movy: v 11-ty tomakh. (1970-1980). [Dictionary of the Ukrainian language: In 11 volumes]. Kyiv: Naukova dumka. [in Ukrainian].

12. Stavytska L. (2000) Estetyka slova v ukrainskii poezii 20-30-kh rr. XX st. [Aesthetics of the word in Ukrainian poetry of the 20-30's of the XX century]. Kyiv: Pravda Yaroslavychiv. 154 p. [in Ukrainian].

13. Osmachka T. (1991). Poezii [Poetry]. Kyiv: Rad. pysmennyk, 252 p. [in Ukrainian].

14. Tresidder Dzh. (1999). Slovar simvolov [Dictionary of symbols]. (Eng. trans.). Moskva: FAIR-PRESS, 448 p. [in Russian].

15. Tsurkan I. (2016). Oleksandr Oles yak medium mizh yevropeiskym ta ukrainskym symvolizmom. [Alexander Oles as a medium between European and Ukrainian symbolism]. Literaturnyi protses: metodolohiia, imena, tendentsii : zb. nauk. statei. Kyiv: Vyd-vo Kyivskoho universytetu imeni Borysa Hrinchenka. S. 107-113. [in Ukrainian].

16. Yusyp-Yakymovych Yu. (2017). Poetychna fonetyka v dzerkali semantyky: akustychnyi (slukhovyi) svit slovianskoho symvolizmu. [Poetic phonetics in the mirror of semantics: the acoustic (auditory) world of Slavic symbolism]. Ukrainske movoznavstvo. Vol. 47/2. P. 101-106. 